PAWEŁ ŁĄCKI

\title{
KULTUROWE UWARUNKOWANIA ROZUMIENIA PRAW CZLOWIEKA NIEMIECKA NAUKA PRAWA WOBEC LEGALIZACJI SPORNYCH PRAKTYK RELIGIJNYCH
}

I. Tocząca się od kilku lat w niemieckiej nauce prawa debata o prawnej dopuszczalności obrzezania stanowi egzemplifikację szerszych problemów, z którymi konfrontowane jest demokratyczne państwo prawa oraz refleksja teoretycznoprawna. Do problemów tych należy określenie istoty i granic prawa rodziców do wychowania dziecka oraz prawa do wolności religijnej, potencjalny konflikt praw i wolności konstytucyjnych, dynamiczna interpretacja praw człowieka związana ze zmieniająca się wrażliwością w zakresie chronionych dóbr, czy wreszcie uzasadnienie i stosowanie uniwersalnych zasad prawa w świetle wzrastającego aksjologicznego pluralizmu współczesnych społeczeństw. Celem niniejszych rozważań jest przedstawienie kształtowania się w Niemczech stanu prawnego dotyczącego obrzezania oraz głównych argumentów podnoszonych w niemieckiej debacie o jego prawnej dopuszczalności. Obrzezanie wykonuje się ze względów religijnych, medycznych lub kulturowych. Praktykowane jest m.in. w judaizmie i islamie. W judaizmie dokonywane jest co do zasady w 8 dniu życia chłopca, w islamie między 7 dniem życia a osiagnięciem dojrzałości płciowej. 20 grudnia $2012 \mathrm{r}$. Bundestag uchwalił ustawę o zakresie pieczy nad osobą przy obrzezaniu dzieci płci męskiej ${ }^{1}$, wprowadzająca do niemieckiego kodeksu cywilnego $\S 1631$ d „Obrzezanie dziecka płci męskiej”. Zgodnie z ust. 1: „Piecza nad osobą obejmuje również prawo do wyrażenia zgody na niepodyktowane względami medycznymi obrzezanie niemającego rozeznania dziecka płci męskiej, o ile ma być ono wykonane zgodnie ze sztuka lekarska. Powyższe nie stosuje się, jeśli obrzezanie, również przy uwzględnieniu jego celu, zagraża dobru dziecka”. Zgodnie z ust. 2: „W okresie pierwszych sześciu miesięcy po urodzeniu dziecka, obrzezanie zgodnie z ust. 1 może być wykonane również przez osoby przewidziane do tego przez związek wyznaniowy, o ile sa one w tym celu wyszkolone, oraz, nie będąc lekarzami, maja porównywalne kwalifikacje do wykonania obrzezania" ${ }^{2}$.

\footnotetext{
${ }^{1}$ Bundesgesetzblatt z 27.12.2012 r.

${ }^{2}$ W Polsce brak regulacji wprost dotyczącej obrzezania. Uważa się, że należy ono do posług religijnych wskazanych w art. 9 ustawy z 20 lutego 1997 r. o stosunku Państwa do gmin wyznaniowych żydowskich (Dz. U. Nr 41, poz. 251 ze zm.), tj. w przepisie, którego „głównym celem [...] jest potwierdzenie swobody [...] udzielania posług religijnych" przez związek wyznaniowy (A. Czo-
} 
II. Bezpośrednim asumptem ${ }^{3}$ do dokonania ww. nowelizacji kodeksu cywilnego był wyrok sądu karnego II instancji - Sądu Krajowego w Kolonii z 7 maja 2012 r. ${ }^{4}$ Stwierdzono w nim, że obrzezanie niepełnoletniego chłopca ze względów religijnych wyczerpuje znamiona czynu sankcjonowanego w $§ 223$ ust. 1 kodeksu karnego (spowodowanie uszczerbku na ciele), a zgoda rodziców nie powoduje wyłączenia bezprawności tego czynu.

W sprawie oskarżonym był lekarz, który na życzenie muzułmańskich rodziców przeprowadził zabieg obrzezania ich czteroletniego syna. Zabieg wykonano prawidłowo pod względem medycznym. Sąd I instancji - Sąd Rejonowy w Kolonii uznał, że bezprawność czynu została wyłączona przez skuteczna zgodę rodziców ${ }^{5}$. Pomimo przyjęcia odmiennej oceny prawnej, sąd odwoławczy podtrzymał uniewinniajaccy wyrok, uznajac, że lekarz działał w usprawiedliwionej nieświadomości bezprawności popełnionego czynu.

Do dnia wejścia w życie ww. nowelizacji nie obowiązywały przepisy wprost regulujące obrzezanie chłopców. Poza wspomnianymi orzeczeniami nie było ono przedmiotem rozstrzygnięć sądów karnych. Z kolei sądy cywilne co do zasady nie kwestionowały dopuszczalności obrzezania za zgodą rodziców 6 . W doktrynie prawa karnego reprezentowane były następujące stanowiska: obrzezanie (1) nie wypełnia znamion czynu zabronionego; (2) wypełnia znamiona czynu zabronionego, ale nie stanowi czynu zabronionego ze względu na zgodę rodziców dziecka; (3) wypełnia znamiona czynu zabronionego, a zgoda rodziców nie może wyłączyć bezprawności ${ }^{7}$.

Proces legislacyjny prowadzacy do uchwalenia ww. nowelizacji przebiegł niezwykle szybko. 19 lipca 2012 r. Bundestag zobowiązał rząd do tego, by „mając na względzie konstytucyjnie chronione wartości prawne: dobro dziecka, nietykalność cielesna, wolność religijną oraz prawo rodziców do wychowania dzieci, przedłożył jesienią 2012 r. projekt ustawy, przewidującej zasadnicza dopuszczalność obrzezania chłopców, które będzie przeprowadzone fachowo pod względem medycznym i bez zbędnego bólu" ${ }^{8}$. W uzasadnieniu wskazano m.in., że wyrok Sądu Krajowego w Kolonii spowodował „głęboką niepewność głównie wśród wyznawców religii żydowskiej i muzułmańskiej” oraz wśród lekarzy. Podkreślono, że ,żydowskie i muzułmańskie życie religijne musi być w dalszym ciągu możliwe w Niemczech”. Ustawę nowelizującą przyjęto w brzmieniu zgodnym z projektem rządowym.

Oprócz projektu rządowego powstał również projekt poselski. Przewidywał zakaz obrzezania chłopców niemających ukończonego 14 roku życia oraz pozbawiał rodziców prawa do podejmowania samodzielnej decyzji w tym zakresie. Nadto wykluczał dopuszczalność wykonywania zabiegu przez osoby

hara, T. J. Zieliński, Ustawa o stosunku Państwa do gmin wyznaniowych żydowskich w Polsce. Komentarz, Warszawa 2012, s. 73).

${ }_{3}$ Zob. J. Isensee, Grundrechtliche Konsequenz wider geheiligte Tradition - Der Streit um die

Beschneidung, „Juristen Zeitung” 2013, nr 7, s. 324.

$4151 \mathrm{Nr} 169 / 11$.

5 Wyrok z 21 września 2011 r., 528 Ds. 30/11.

${ }^{6}$ Zob. Rzqdowy projekt ustawy o zakresie pieczy nad osoba przy obrzezaniu dzieci płci męskiej, Deutscher Bundestag, druk 17/11295, s. 12 (dalej: RPU).

7 Ibidem, s. 11-12.

8 Deutscher Bundestag, druk 17/10331. 
wyznaczone przez związek wyznaniowy, niebędące lekarzami o specjalności chirurga dziecięcego lub urologa ${ }^{9}$.

Istnieją spory, czy nowelizacja spowodowała zmianę stanu prawnego, czy też potwierdziła jedynie stan dotychczasowy. Rozstrzygnięcie tej kwestii związane jest z oceną poprawności stanowiska Sądu Krajowego w Kolonii ${ }^{10}$. Niektórzy przedstawiciele doktryny, pomimo wyrażenia krytycznej oceny stanowiska przyjętego przez sąd, uznali zasadność ingerencji ustawodawcy ze względu na potrzebę usunięcia niepewności pojawiającej się m.in. w środowiskach prawniczych i medycznych ${ }^{11}$.

W doktrynie brak zgodności co do oceny konstytucyjności ustawy nowelizującej ${ }^{12}$. Można spotkać głosy zarówno uznające ustawę za niekonstytucyjną ${ }^{13}$, jak i za zgodna z Ustawą zasadniczą (dalej jako: UZ) ${ }^{14}$. Sformułowano również pogląd, iż ustawa jest „konstytucyjnie wątpliwa”, niemniej politycznie uzasadniona - zapobiega bowiem „wojnie kulturowej”, która w żadnym razie nie powinna toczyć się w Niemczech ${ }^{15}$.

III. Równolegle z kształtowaniem się stanu prawnego wśród przedstawicieli nauki prawa toczyła się dyskusja, zarówno de lege lata, jak i de lege ferenda. Niezależnie od ww. rozstrzygnięcia ustawodawcy, toczy się ona dalej. Przedmiotowa kwestię podejmowano wprawdzie przed wydaniem wyroku przez Są Krajowy w Kolonii ${ }^{16}$, jednakże wskutek ww. orzeczenia akademicka dyskusja radykalnie zintensyfikowała się i rozszerzyła na debatę publiczna, polityczna, wreszcie parlamentarna, związana z pracami legislacyjnymi. Debata ta, również w ramach nauki prawa, miała miejscami charakter gwałtowny i emocjonalny. Przyczyn takiego stanu rzeczy można upatrywać m.in. w tym, że w społeczeństwie naznaczonym szczególną winą i pamięcią dotyczącą Holocaustu pod znakiem zapytania znalazł się „religijny ryt [...], który bez przeszkód wykonywany był przez Żydów pod panowaniem prawie wszystkich reżimów w historii, zarówno tolerancyjnych, jak i nietolerancyjnych"17.

Pomimo że orzeczenie sądu w Kolonii dotyczyło stosowania przepisów prawa karnego, a ingerencja ustawodawcy nastapiła na gruncie prawa cy-

${ }_{9}$ Poselski projekt ustawy M. Rupprecht i in., Deutscher Bundestag, druk 17/11430.

${ }^{10}$ Por. np. Ch. Walter, [Opinia dla komisji prawnej Bundestagu], 22 listopada 2012 r., s. 8; opinia ta oraz pozostałe opinie sporządzone dla komisji prawnej Bundestagu dostępne są na: http://webarchiv.bundestag.de/ [dostęp: 1.11.2014].

${ }_{11}$ Por. S. Willutzki, Zum Umfang der Personensorge bei der Beschneidung. Stellungnahme zur Anhörung im Rechtsausschusss [Opinia dla komisji prawnej Bundestagu], s. 1.

12 Przegląd stanowisk w: A. Eser, [Komentarz do § 223], w: A. Eser (Hrsg.), Schönke/ Schröder. Strafgesetzbuch. Kommentar, wyd. 29, München, nb. 12c.

${ }_{13}$ Zob. np.: H. Putzke, Die Beschneidungsdebatte aus Sicht eines Protagonisten. Anmerkungen zur Entstehung und Einordnung des Beschneidungsurteils sowie zum Beschneidungsparagrafen ( $\$ 1631 d$ BGB) und zu seinen Konsequenzen, w: M. Franz (Hrsg.), Die Beschneidung von Jungen: Ein trauriges Vermächtnis, Göttingen 2014, s. 354.

${ }_{14}$ Zob. np. H. Radtke, [Opinia dla komisji prawnej Bundestagu], s. 9.

15 Zob. J. Isensee, op. cit., s. 327.

${ }_{16}$ Dyskusję zapoczątkował H. Putzke tekstem Die strafrechtliche Relevanz der Beschneidung von Knaben. Zugleich ein Beitrag über die Grenzen der Einwilligung in Fällen der Personensorge, w: H. Putzke et al. (Hrsg.), Strafrecht zwischen System und Telos, Festschrift für Rolf Dietrich Herzberg, Tübingen 2008, s. 669-709.

17 J. Isensee, op. cit., s. 323. 
wilnego, rozstrzygający dla prawnej oceny obrzezania wydaje się aspekt konstytucyjny ${ }^{18}$.

Problematykę obrzezania dyskutuje się najczęściej w świetle następujących praw podstawowych gwarantowanych w UZ: 1) prawa do integralności cielesnej (art. 2 ust. 2 zd. 1: „Każdy ma prawo [...] do nietykalności osobistej”), 2) prawa rodziców do wychowana dzieci (art. 6 ust. 2: „Opieka nad dziećmi i ich wychowanie sa przyrodzonym prawem rodziców, a przede wszystkim ich powinnościa. Nad jej wypełnianiem czuwa wspólnota państwowa"), 3) prawa do wolności religijnej zarówno rodziców, jak i dziecka (art. 4 ust. 1: „Wolność wyznania, sumienia i swoboda przekonań religijnych i światopoglądowych sa nienaruszalne”; ust. 2: „Zapewnia się swobodę praktyk religijnych”). Przeważa przy tym stanowisko, że dopuszczalność obrzezania rozstrzyga się na poziomie konstytucyjnym, tj. albo że jest ono niedopuszczalne w świetle UZ, albo że jego dopuszczalność wynika z postanowień UZ.

Oprócz odmiennej oceny prawnej obrzezania przeciwnicy i zwolennicy jego dopuszczalności ${ }^{19}$ prezentują odmienną ocenę faktycznych okoliczności związanych z tym zabiegiem. Z jednej strony zabieg kwalifikowany jest jako „ciężkie”"20, „bolesne i niebezpieczne uszkodzenie ciała”21, „inwazyjna ingerencja mająca poważne konsekwencje" ${ }^{22}$, o nieodwracalnych skutkach i wywołująca „stan patologiczny" ${ }^{23}$, wiążąca się zawsze z ryzykiem²4; ma on być źródłem traumy seksualnej ${ }^{25}$, stanowić pozbawienie części ciała, która spełnia funkcję wzmacniania odczuć seksualnych ${ }^{26}$ czy być „krwawym rytuałem przeprowadzanym na dziecku”27. Z drugiej strony, przyznajac, że jest to „ingerencja w nietykalność cielesną związana z ryzykiem i mająca niebagatelny charakter" ${ }^{28}$, podkreśla się, że prawidłowo przeprowadzone obrzezanie nie wywołuje negatywnych konsekwencji zdrowotnych ${ }^{29}$, w tym zaburzenia funkcji

18 Zob. M. Germann, Die Vorgaben des Grundgesetzes für die Beschneidungsdebatte, „epd-Dokumentations" 2012, nr 48, s. 37.

19 Przez pojęcie „przeciwnicy...” należy rozumieć dyskutantów uważających obrzezanie za niedopuszczalne konstytucyjnie; przez pojęcie „zwolennicy...” - uważających je za konstytucyjnie dopuszczalne.

${ }^{20}$ R. Merkel, H. Putzke, After Cologne: male Circumcision and the Law-Parental right, religious liberty, or criminal assault?, „Journal of Medical Ethics” 2013, nr 39, s. 446.

${ }^{21}$ Por. R.D. Herzberg, Ethische und rechtliche Aspekte der Genitalbeschneidung, w: M. Franz (red.), Die Beschneidung von Jungen: Ein trauriges Vermächtnis, Göttingen 2014, s. 292.

22 J. Isensee, op. cit., s. 321.

${ }^{23}$ F. Czerner, Staatlich legalisierte Kindeswohlgefährdung durch Zulassung ritueller Beschneidung zugunsten elterlicher Glaubensfreiheit?, „Zeitschrift für Kindschaftsrecht und Jugendhilfe" 2012 , nr 10, s. 378.

${ }^{24}$ R. D. Herzberg, Die Beschneidung gesetzlich gestatten?, „Zeitschrift für Internationale Strafrechtsdogmatik" 2012, nr 10, s. 488.

${ }^{25}$ G. Jerouschek, Beschneidung und das deutsche Recht. Historische, medizinische, psychologische und juristische Aspekte, „Neue Zeitschrift für Strafrecht” 2008, nr 6, s. 316.

${ }_{26}$ J. Scheinfeld, Die Knabenbeschneidung im Lichte des Grundgesetzes, w: M. Franz (Hrsg.), op. cit., s. 366 .

27 R. D. Herzberg,op. cit., s. 494.

${ }_{28}$ T. Hörnle, S. Huster, Wie weit reicht das Erziehungsrecht der Eltern? Am Beispiel der Beschneidung von Jungen, „JuristenZeitung” 2013, nr 7, s. 339.

${ }_{29}$ Zob. B. Fateh-Moghadam, Strafrecht und Religion im liberalen Rechtsstaat. Juristische Argumente gegen die Kriminalisierung der Beschneidung, w: J. Heil, S. J. Kramer (Hrsg.), Beschneidung: Das Zeichen des Bundes in der Kritik: Zur Debatte um das Kölner Urteil, Berlin 2012, s. 152. 
organu $^{30}$, ewentualnie, że nie ma dowodów, by miało „poważne cielesne lub psychiczne konsekwencje" ${ }^{31}$, w tym powodowało traumę ${ }^{32}$. Również w aspekcie wpływu na życie seksualne wskazuje się na rozbieżność opiniii ${ }^{33}$. Zabieg wiąże się z niewielkim ryzykiem ${ }^{34}$, a „powikłania są »bardzo rzadkie i najczęściej nieistotne "35. Niektórzy uważaja, że ma pozytywne skutki zdrowotne o charakterze prewencyjnym, w szczególności zmniejsza ryzyko zachorowania na pewne choroby ${ }^{36}$.

Przeciwnicy dopuszczalności obrzezania uznają je za nieusprawiedliwiona ingerencję w prawo dziecka do nietykalności cielesnej, ewentualnie również w inne dobra chronione dziecka. Wydaje się, że punktem wyjścia rozważań przeciwników dopuszczalności obrzezania jest „domniemanie na rzecz integralności cielesnej chłopców" 37 i uznanie szczególnej rangi chronionego dobra - integralności cielesnej ${ }^{38}$. Wskazuje się, ze obrzezanie stanowi naruszenie prawa do nietykalności cielesnej ${ }^{39}$. Twierdzi się, że oczywistością jest, iż „bez istotnych wskazań medycznych rodzice nie mogą spowodować usunięcia erogennej części z seksualnego organu swojego dziecka" ${ }^{40}$. Dokonanie takiego uszczerbku na ciele nie może być usprawiedliwione ani prawem rodziców do wolności religijnej, ani prawem do wychowania dziecka. Obrzezanie wypełnia znamiona uszkodzenia ciała i nie ma w tym przypadku podstaw do skutecznego wyłączenia bezprawności ${ }^{41}$.

Argumentuje się, że dopuszczalność obrzezania nie może być uzasadniona prawem rodziców do wolności religijnej, która jest „czystym prawem wolnościowym” ${ }^{2}$ : „nie ma czegoś takiego, jak uprawnienie do bezpośredniego wyrządzenia komuś uszczerbku na ciele według swobodnego uznania" ${ }^{43}$. Wolność religijna „nie przyznaje rodzicom prawa do czynienia z dziecka narzędzia i przedmiotu ich przekonań religijnych” ${ }^{44}$, a „zakres ochrony wolności religijnej jednej osoby musi się [...] tam kończyć, gdzie zaczyna się sfera praw podstawowych drugiej osoby" ${ }^{45}$. Stąd część przeciwników dopuszczalności obrzezania uważa, że nie występuje w ogóle konflikt między prawem do nietykalności cielesnej dziecka a prawem rodziców do wolności religijnej, jako że obrzezanie nie jest objęte przysługującym rodzicom prawem: „wolność religijna [...] rodziców

\footnotetext{
${ }^{30}$ A. Steinbach, Die gesetzliche Regelung zur Beschneidung von Jungen, „Neue Zeitschrift für Verwaltungsrecht-Extra" 2013, nr 9, s. 7.

${ }^{31}$ M. Germann, Die Vorgaben des Grundgesetzes..., s. 45-6.

${ }^{32}$ Por. RPU, op. cit., s. 9.

${ }^{33}$ Ibidem.

${ }^{34}$ Zob. B. Fateh-Moghadam, Strafrecht und Religion im liberalen Rechtsstaat..., s. 153.

${ }^{35}$ RPU, op. cit., s. 9.

${ }^{36}$ Zob. B. Fateh-Moghadam, Strafrecht und Religion im liberalen Rechtsstaat..., s. 152.

${ }^{37}$ M. Morlok, Glaubens-, Gewissens- und Bekenntnisfreiheit, Kriegsdienstverweigerung, w: H. Dreier (Hrsg.), Grundgesetz, Bd. 1: Präambel, Artikel 1-19, Tübingen 2013, nb. 81.

${ }^{38}$ Zob. R. Merkel, H. Putzke, op. cit., s. 445.

${ }^{39}$ J. Scheinfeld, op. cit., s. 364.

${ }^{40}$ Ibidem, s. 367.

${ }^{41}$ H. Putzke, Die strafrechtliche Relevanz der Beschneidung von Knaben..., s. 707.

${ }^{42}$ R. Merkel, H. Putzke, op. cit., s. 446.

${ }^{43}$ Ibidem.

${ }^{44}$ F. Czerner, op. cit., s. 380.

${ }^{45}$ R. Eschelbach, [Komentarz do art. 223], w: B. Heintschel-Heinegg (Hrsg.), Beck'scher Onlinekommentar zum StGB, (wyd. 23), 2014, nb. 35.2.
} 
nie może być uwzględniana $\mathrm{w}$ jakiejkolwiek rozsądnej argumentacji zmierzającej do uzasadnienia dopuszczalności religijnie motywowanego obrzezania"46.

Również prawo do wychowania dziecka nie może uzasadnić dopuszczalności obrzezania. Argumentuje się, że o ile w ramach przysługującego rodzicom prawa mogą oni w niektórych przypadkach skutecznie wyrazić zgodę na ingerencję w nietykalność cielesną dziecka, to obrzezanie nie stanowi takiego przypadku ${ }^{47}$.

Nadto wskazuje się, że zgoda rodziców na ingerencję w nietykalność cielesną dziecka jest wyłącznie dopuszczalna w celu realizacji dobra dziecka, z kolei obrzezanie niepodejmowane ze względów medycznych nie służy dobru dziecka $^{48}$, a dobro to jest w „konkretny sposób zagrożone” ${ }^{49}$. Obrzezanie jest „obiektywnie" niekorzystne dla dziecka ${ }^{50}$ i nie leży w jego interesie ${ }^{51}$. Rzeczą zaś państwa jest zapobiegać wyrządzeniu dziecku szkód, w tym szkód na ciele ${ }^{52}$.

Nawet jeśli identyfikuje się korzyści obrzezania dla dziecka, to uznaje się, że jego szkodliwość przeważa nad korzyściami. W odniesieniu do religijnego obrzezania przedstawiono następujące zestawienie szkód i korzyśsici ${ }^{53}$. Po stronie szkód wskazano: 1) „istotne uszkodzenie nietykalności cielesnej”, 2) „ryzyko w trakcie i po operacji”, 3) „obciążenie psychiczne”, 4) „nieodwracalność ingerencji” ${ }^{54}$. Identyfikując korzyści, przyjęto założenie, że muszą one być „mierzalne i dające się racjonalnie uzasadnić” 55 ; korzyść obrzezania ma polegać na tym, że stanowi „narzędzie tożsamości” i pozwala uniknąć dziecku negatywnych konsekwencji społecznych, w szczególności stygmatyzacji we wspólnocie, w której praktykuje się obrzezanie ${ }^{56}$. Biorąc jednak pod uwagę, że „obrzezanie jest szkodliwe dla zdrowia”, korzyść nie przeważa nad szkodami ${ }^{57}$.

Wyrażono również pogląd, że obrzezanie, wpływając na odczucia seksualne w przyszłości, ingeruje w prawa do rozwoju osobowości (art. 2 ust. 1 UZ: „Każdy ma prawo do swobodnego kształtowania swojej osobowości [...]") ${ }^{58}$ oraz że stanowi naruszenie godności człowieka (art. 1 zd. 1 UZ: „Godność człowieka jest nienaruszalna”), czy to ze względu na ingerencję w „prawo do określenia się w wymiarze seksualnym i niezakłócony rozwój dziecka w wymiarze seksualnym i ogólnym" "59, czy też ze względu na mające charakter stygmatyzacji widoczne przyporządkowanie na całe życie do danej wspólnoty religijnej ${ }^{60}$. Nadto uważa się, że dopuszczalności obrzezania nie da się pogodzić z ustawowym

\footnotetext{
${ }^{46}$ R. Merkel, H. Putzke, op. cit., s. 446.

${ }^{47}$ H. Putzke, Die strafrechtliche Relevanz der Beschneidung von Knaben..., s. 683 i n.

${ }^{48}$ Ibidem, s. 707.

${ }^{49}$ R. Eschelbach, op. cit., nb. 35.7.

${ }^{50}$ R. D. Herzberg, Ethische und rechtliche Aspekte..., s. 296.

51 F. Czerner, op. cit., s. 378.

52 J. Isensee, op. cit., s. 320 i 321.

${ }^{53}$ H. Putzke, Die strafrechtliche Relevanz der Beschneidung von Knaben..., s. 687.

${ }^{54}$ Ibidem, s. 700-701.

55 Ibidem.

56 Ibidem, s. 701 i 702.

57 Ibidem, s. 705 i 707.

58 J. Scheinfeld, op. cit., s. 365.

59 R. Eschelbach, op. cit., nb. 35.

${ }^{60}$ G. Jerouschek, op. cit., s. 319.
} 
zakazem stosowania przemocy wobec dzieci (§ 1631 ust. 2 zd. 1 niemieckiego kodeksu cywilnego: „Dzieci mają prawo do wychowania bez przemocy”).

Wśród zwolenników dopuszczalności obrzezania można spotkać stanowisko, że dopuszczalność ta jest wymagana przez UZ, jak i stanowisko, że jest ona konstytucyjnie obojętna. Co do zasady uważają oni, że rodzice w ramach prawa do wychowywania dzieci mogą skutecznie wyrazić zgodę na obrzezanie, gdy jest ono przeprowadzone zgodnie ze sztuką lekarską i podejmowane z ważkich powodów, w szczególności jako obrzęd religijny, względnie gdy nie jest dokonywane w celach sprzecznych z dobrem dziecka. Argumentuje się również, że zakaz obrzezania stanowiłby naruszenie prawa do wolności religijnej.

Zwolennicy dopuszczalności obrzezania zwracają uwagę na specyficzna konstrukcję prawa do wychowania dzieci. Wpływa ona na normatywna ocenę obrzezania oraz na specyfikę zestawienia i ,ważenia” prawa dziecka do nietykalności cielesnej i prawa rodziców do wychowania dziecka. Relewantny ma być obronny aspekt prawa rodziców do wychowania dziecka ${ }^{61}$ oraz ochronny aspekt prawa do nietykalności cielesnej. Biorąc pod uwagę, że postanowienia UZ w zakresie praw podstawowych adresowane są do państwa ${ }^{62}$, prawo obronne zakazuje państwu ingerencji w sferę wolności jednostki; prawo ochronne nakłada zaś obowiązek podjęcia działań w celu ochrony jednostek przed ingerencja ze stronny innych. W tym kontekście wyklucza się możliwość abstrakcyjnego zestawienia i „ważenia” prawa od nietykalności cielesnej i prawa rodziców do wychowania dziecka ${ }^{63}$. Wskazuje się nadto na „asymetryczną sytuację ważenia [praw], ponieważ należy wychodzić od pierwszeństwa prawa rodziców do wychowania dziecka jako prawa obronnego wobec państwa"64.

Prawo rodziców do wychowania dziecka ma „nietypową konstrukcję: „ustanawia wolność rodziców, z drugiej strony zawiera obowiązek" "65; podstawowa zasada jego wykonywania jest dobro dziecka. Państwo, czuwając nad wykonywaniem tego prawa, ukierunkowane jest również na dobro dziecka. Pojęcie dobra dziecka w aspekcie prawa rodziców zawiera subiektywne elementy: „rodzice sami wpływają na jego konkretna treść, czyli na to, co jest dla dziecka "dobre«" 66 . Natomiast pojęcie to w aspekcie zadań kontrolnych państwa ma charakter zobiektywizowany. Jego określenie następuje „z zewnętrznej perspektywy »obiektywnej osoby trzeciej«"67, a obiektywizacja ta służy określeniu granic, których przekroczenie uzasadnia ingerencję państwa.

Wychowanie dziecka należy co do zasady do rodziców: „Rodzice moga, zasadniczo w sposób wolny od wpływu i ingerencji państwa, podejmować decyzję co do tego, jak będą kształtować opiekę i wychowanie swoich dzieci"68. Państwo

61 RPU, op. cit., s. 12.

62 M. Germann, Die Vorgaben des Grundgesetzes für die Beschneidungsdebatte..., s. 39.

${ }^{63}$ M. Germann, Die Verfassungsmäßigkeit des Gesetzes über den Umfang der Personensorge bei einer Beschneidung des männlichen Kindes vom 20.12.2012, „Medizinrecht” 2013, nr 31, s. 413.

64 T. Hörnle, S. Huster, op. cit., s. 332.

${ }^{65}$ Ch. Walter, op. cit., s. 2.

66 Ibidem.

${ }^{67}$ T. Hörnle, S. Huster, op. cit., s. 332.

68 RPU, op. cit., s. 12. 
nie jest „upoważnione do konkurencyjnego w stosunku do rodziców określenia optimum w zakresie dobra dziecka"69; nie może rozstrzygać, czy obrzezanie służy dobru dziecka, i ingerować w sferę praw rodziców w przypadku, gdy uzna, że obrzezanie nie służy dobru dziecka ${ }^{70}$.

Ingerencja w prawo rodziców uzasadniona jest jedynie w przypadku, gdy dobro dziecka jest zagrożone $\mathrm{e}^{71}$, a „zadanie państwa ogranicza się [...] do "ochrony przed zagrożeniami w wyjątkowych przypadkach«, gdy sytuacja rodzinna "według powszechnych ocen jest dla dziecka nie do zniesienia""72. Do zagrożenia dobra dziecka dochodzi dopiero wówczas, gdy decyzja rodziców podejmowana w stosunku do dziecka „w sposób wyraźny i jednoznaczny” sprzeciwia się dobru dziecka ${ }^{73}$; gdy „dla dziecka powstaje aktualne, w takim stopniu występujące zagrożenie, że niemal z pewnością należy liczyć się z istotną szkodą dla jego dalszego rozwoju"74. W przypadku gdy analizę w zakresie ewentualnego zagrożenia dobra dziecka przedstawia się w schemacie ważenia korzyści i szkód, wskazuje się, że do zagrożenia dochodzi dopiero w przypadkach, gdy „ryzyko przeważa na korzyściami w takim zakresie, że nie da się już go ujaćc jako akceptowalne"75. Nie każde błędne rozstrzygnięcie rodziców uzasadnia ingerencję państwa. Ingerencja powinna mieć „subsydiarny i wyjątkowy”76 charakter.

Wskazuje się, że dobro nietykalności cielesnej może podlegać ograniczeniu ${ }^{77}$. Zaprzecza się twierdzeniu, by w świetle UZ dobru temu „per se przysługiwało pierwszeństwo wobec dobra, jakim jest rodzicielskie prawo sprawowania pieczy nad dzieckiem”78, tudzież by „każda ingerencja w cielesną nietykalność, która nie jest podyktowana względami medycznymi, per se stanowiła przekroczenie rodzicielskich uprawnień"79. To, jaką rangę należy przyznać dobru nietykalności cielesnej „w przypadku konkretnej kolizji dóbr prawnych, rozstrzyga się według zasady proporcjonalności, każdorazowo przy uwzględnieniu konkretnych okoliczności" ${ }^{80}$. Z kolei dobro dziecka nie może być rozpatrywane jedynie w aspekcie fizycznym czy medycznym, ale w aspekcie „całościowego rozwoju osobowego dziecka" ${ }^{81}$. Pogląd, że obrzezanie jako takie zagraża dobru dziecka, ma być wyrazem „państwowego paternalizmu w zakresie rozumienia dobra dziecka" ${ }^{\prime 2}$.

\footnotetext{
${ }^{69}$ M. Germann, Die Verfassungsmäßigkeit des Gesetzes..., s. 414.

70 Por. S. Willutzki, op. cit., s. 2.

71 Zob. H. Radtke, op. cit., s. 10.

${ }^{72}$ T. Hörnle, S. Huster, op. cit., s. 332.

${ }^{73}$ Ch. Walter, op. cit., s. 6.

${ }^{74}$ S. Willutzki, op. cit., s. 3.

75 N. Steiner, Die religiös motivierte Knabenbeschneidung im Lichte des Strafrechts: Zugleich ein Beitrag zu Möglichkeiten und Grenzen elterlicher Einwilligung, Berlin 2014, s. 232.

76 Ibidem, s. 231.

77 Zob. A. Steinbach, op. cit., s. 9.

78 H. M. Heining, [Opinia dla komisji prawnej Bundestagu, 20 listopada 2012 r.], s. 5.

${ }^{79}$ T. Hörnle, S. Huster, op. cit., s. 333.

${ }^{80}$ H. M. Heining, [Opinia dla komisji prawnej Bundestagu, 20 listopada 2012 r.], s. 5.

81 Ch. Walter, op. cit., s. 5.

82 B. Fateh-Moghadam, Strafrecht und Religion im liberalen Rechtsstaat..., s. 150.
} 
Według zwolenników dopuszczalności obrzezania, gdy są spełnione pewne warunki, nie dochodzi do naruszenia dobra dziecka uzasadniającego ingerencję państwa $\mathrm{w}$ rodzicielską pieczę ${ }^{83}$. W szczególności obok wykonywania zabiegu w sposób zgodny ze sztuką lekarska, przez co rozumie się również minimalizowanie bólu ${ }^{84}$, podkreśla się wagę celów, w jakich jest ono podejmowane. Analiza celów, które uzasadniałyby dopuszczalność obrzezania, jest przeprowadzana w literaturze w różny sposób. Co do zasady wyklucza się dopuszczalność dokonywania zabiegu „lekkomyślnie”.85.

Wskazuje się, że „rodzice w oparciu o różne racje mogą uznawać niemotywowane medycznie obrzezanie za służące dobru dziecka"86. Obrzezanie może być rytuałem religijnym czy tradycyjnym obrzędem kulturowym; nadto może być uzasadniane profilaktyka. Istotne, by przez rodziców było podejmowane „dla cielesnej [...] lub duchowej pomyślności dziecka”87. Tego warunku nie spełniałoby obrzezanie jako sankcja za złe zachowanie dziecka, obrzezanie z czysto estetycznych powodów czy po to, by utrudnić dziecku masturbację ${ }^{88}$.

Niektórzy autorzy rozpatrując cele, dla których obrzezanie byłoby dopuszczalne, wskazuja na względy religijne. W przypadku bowiem, gdy cel obrzezania nie zasługuje na odpowiednią ochronę, nie można, w rezultacie procesu ważenia dóbr, przyznać pierwszeństwa prawu rodziców wobec prawa dziecka do nietykalności cielesnej ${ }^{89}$. Zarazem można spotkać pogląd, że również w innych przypadkach zachodzi dopuszczalność obrzezania, a dopuszczalność obrzezania motywowanego religijnie wynika „z ogólnego określenia zakresu i granic prawa rodziców do sprawowania pieczy nad dzieckiem”90.

Określając kryteria dopuszczalności obrzezania, przyjmuje się, że należy m.in. uwzględnić, ,jaki przekaz społeczny związany jest z procedurą obrzezania w odniesieniu do dzieci”"91; obrzezanie powinno „dać się ujać jako element niekoniecznie religijnej, ale w każdym razie całościowej i co do zasady rozsądnej wizji wychowawczej" ${ }^{2}$. W przypadku od dawna istniejących wspólnot religijnych, posiadających znaczną liczbę wyznawców, można domniemywać występowanie takiej stabilnej, zasadniczo nieszkodliwej wizji wychowawczej [...]"93. Argumentuje się, że „z reguły obrzezanie nie stanowi nadużycia rodzicielskiej pieczy”94 w oparciu o weryfikację następujących kryteriów: 1) rozmiaru ingerencji i jej zdrowotnych konsekwencji, 2) korzyści zapobiegawczo-medycznych związanych z obrzezaniem, 3) braku okoliczności upokarzających dziecko.

${ }^{83}$ Zob. B. Fateh-Moghadam, Religiöse Rechtfertigung? Die Beschneidung von Knaben zwischen Strafrecht, Religionsfreiheit und elterlichem Sorgerecht, „Rechtswissenschaft” 2010, nr 2, s. $151 \mathrm{i} \mathrm{n.}$

${ }^{84}$ Tak w RPU, op. cit., s. 17.

${ }^{85}$ T. Hörnle, S. Huster, op. cit., s. 339.

$86 R P U$, op. cit., s. 16.

87 Ibidem.

88 Ibidem, s. 16 i 18.

89 A. Steinbach, op. cit., s. 9.

90 B. Fateh-Moghadam, Religiöse Rechtfertigung?..., s. 139.

91 T. Hörnle, S. Huster, op. cit., s. 335.

92 Ibidem, s. 339.

${ }^{93}$ Ibidem, s. 334.

${ }_{94}$ B. Fateh-Moghadam, Religiöse Rechtfertigung?..., s. 133-138. 
W odniesieniu do religijnego obrzezania uważa się, że nie będąc przemoca czy czynnością poniżająca ${ }^{95}$ jako rytuał inicjacyjny, ma „przyczyniać się do [...] rozwoju osobowości jednostki”, ma być impulsem do „pozytywnego kształtowania tożsamości” i poprzez nie ma „zwiększać się pomyślność dziecka”.

$\mathrm{W}$ analizowanej debacie zestawiano również obrzezanie chłopców z obrzezaniem dziewczynek. W tym kontekście przeciwnicy dopuszczalności obrzezania zarzucali swoim polemistom niespójność polegająca na braku akceptacji dopuszczalności obrzezania dziewczynek ${ }^{97}$. Zwolennicy dopuszczalności obrzezania podkreślali natomiast, że obrzezanie chłopców istotnie różni się od okaleczania genitaliów żeńskich ${ }^{98}$, co uzasadnia odmienną kwalifikację prawną. Można spotkać też stanowisko, iż „łagodne” formy religijnie motywowanego obrzezania łechtaczki, których konsekwencje sa porównywalne do obrzezania napletka”, powinny być traktowane analogicznie do obrzezania chłopców ${ }^{99}$.

Płaszczyzną sporu jest również ocena wpływu obrzezania na wolność religijną w wymiarze negatywnym. Dla przeciwników dopuszczalności obrzezania stanowi ono naruszenie negatywnej wolności religijnej dziecka jako „wymuszony wybór wyznania religijnego"100: „w sposób nieodwracalny wpływa na religijne [...] samookreślenie dziecka, ponieważ wskutek obrzezania pozostaje rozpoznawalna [...] przynależność do judaizmu lub islamu, a chłopiec [...] przez całe życie jest skonfrontowany z symbolem religijnym. W obrzezaniu wyraża się akt religijnej heteronomii, którego nie można już skorygować, nawet wówczas, gdy chłopiec po osiągnięciu dojrzałości religijnej będzie chciał należeć do innego lub nie należeć do żadnego wyznania"101. Przesłanką tego argumentu wydaje się fizyczna nieodwracalność skutków obrzezania. Można spotkać również pogląd, zgodnie z którym okoliczność, że „dziecku na całe życie zostaje nadany znak tożsamości religijnej”, nie tyle uniemożliwia, ile „może mu w przyszłości utrudnić podjęcie decyzji na rzecz innej religii [...]"102. Niedopuszczalne ma być trwałe oznaczenie ciała dziecka podjęte w celach religijnych jako sprzeczne z jego prawem do przyjęcia lub odrzucenia danej religii: „skoro rodzice nie mają prawa do określenia religijnej przynależności dziecka na całe życie, dlaczego mieliby mieć prawa do trwałego oznaczenia ciała swojego dziecka symbolem takiej przynależności? Przy tym jest nieistotna okoliczność, że ten znak jest wieloznaczny i niekoniecznie wskazuje na przynależność religijna: został wyryty na ciele dziecka jedynie w tym celu”103.

${ }^{95}$ K. Zähle, Religionsfreiheit und fremdschädigende Praktiken, „Archiv des öffentlichen Rechts" 2009, nr 134, s. 446 i 447.

96 Ibidem, s. 452.

97 J. Scheinfeld, op. cit., s. 378.

98 RPU, s. 13-14.

99 A. Steinbach, op. cit., s. 10.

100 F. Czerner, op. cit., s. 379 i 382.

101 F. Brosius-Gersdorf, Ehe und Familie, Elternrecht, Wächteramt, Trennungsamt, Mutterschutz, uneheliche Kinder [Komentarz], w: H. Dreier (Hrsg.), Grundgesetz, Bd. 1: Präambel, Artikel 1-19, Tübingen 2013, nb. 163.

102 J. Scheinfeld, op. cit., s. 365.

103 Zob. np. R. Merkel, H. Putzke, op. cit., s. 447. 
Z kolei zwolennicy dopuszczalności obrzezania uważaja, że nie ogranicza ono negatywnej wolności religijnej - dziecko może przecież w przyszłości dokonywać wyborów światopoglądowych. Bycie obrzezanym nie ogranicza możliwości porzucenia religii czy wyboru innej ${ }^{104}$. Nadto biorąc pod uwagę, że jest ono „praktykowane w różnych religiach [...], a często podejmowane jest $\mathrm{z}$ innych niż religijne względów [...], okoliczność bycia obrzezanym nie umożliwia stwierdzenia przynależności do danej wspólnoty religijnej” ${ }^{105}$. Sama nieodwracalność skutków obrzezania nie powoduje naruszenia negatywnej wolności religijnej dziecka. Każde wychowanie, nie tylko religijne, wywiera w nieunikniony sposób wpływ na dziecko ${ }^{106}$. Zwrócono również uwagę, że o ile obrzezanie ma charakter nieodwracalny w aspekcie cielesnym, jego brak może mieć nieodwracalne konsekwencje społeczno-kulturowe: „w przypadku gdy pełna przynależność do wspólnoty religijnej może zostać osiagnięta jedynie poprzez dokonanie obrzezania w określonym terminie, po upływie terminu nie da się już tego skorygować"107.

Na zakończenie przeglądu argumentów podnoszonych w debacie o obrzezaniu warto zauważyć, że w wypowiedziach przeciwników jego dopuszczalności charakterystyczne jest podkreślanie odrębności interesów dziecka i rodziców oraz konfliktu między ich interesami w przypadku obrzezania: „dziecko jest dla rodziców kimś innym: osoba, od początku obdarzoną we własne prawa podstawowe"108. Nadto abstrakcyjnie charakteryzując pozycję prawną rodziców i dziecka, wskazuje się niekiedy na (potencjalne) zagrożenia dziecka ze strony rodziców ${ }^{109}$. W stanowiskach zwolenników dopuszczalności obrzezania uwidacznia się przekonanie o szczególnej pozycji prawnej rodziców wobec dziecka w świetle postanowień UZ: „Rodzice sa powiernikami praw dziecka. [...] nie są typowym podmiotem trzecim, który stwarza zagrożenie, ale znajdują się $\mathrm{w}$ powierniczej sytuacji, co z kolei, w porównaniu z innymi, normalnymi kolizjami praw podstawowych, wyznacza dla środków stosowanych przez ustawodawcę wyższy próg, jeśli ustawodawca chce zakazać czegoś rodzicom"110. Podkreśla się, że „rodzice i dzieci w świetle przysługujących im praw podstawowych nie sa wobec siebie wrogo nastawieni, co więcej, wykonywanie praw dzieci następuje przez ich rodziców”"11.

IV. W analizowanej debacie istota sporu ogniskuje się na pytaniu, czy przy obrzezaniu dochodzi do zagrożenia dobra dziecka, uzasadniającego ingerencję w prawo rodziców do wychowania dziecka. Spór dotyczy również samej identyfikacji interesów i pozycji prawnych, jak i ich konstelacji, istotnych dla odpowiedzi na pytanie o dopuszczalność obrzezania, m.in. czy domniemanie

${ }_{104}$ Zob. np. B. Fateh-Moghadam, Strafrecht und Religion im liberalen Rechtsstaat..., s. 155.

105 Ibidem.

106 T. Hörnle, S. Huster, op. cit., s. 329.

107 Ch. Walter, op. cit., s. 5.

108 J. Isensee, op. cit., s. 319.

109 Zob. ibidem, s. 295.

${ }_{110}$ H. M. Heining, w: Deutscher Bundestag, Protokót ze 102 posiedzenia komisji prawnej, 26 listopada 2012 r., s. 38.

111 B. Fateh-Moghadam, op. cit., s. 150. 
pierwszeństwa należy przypisać prawu do nietykalności cielesnej dziecka czy prawu rodziców do wychowania dziecka. To z kolei wpływa na ocenę potrzeby uwzględnienia motywów podejmowania obrzezania. O ile z perspektywy skutków obrzezania dla nietykalności cielesnej dziecka motywy rodziców sa obojętne, w świetle ważenia interesów prawnych, niezbędnego w celu odpowiedzi na pytanie o dopuszczalność obrzezania, może to mieć znaczenie.

Spór w kwestii zagrożenia dobra dziecka wiąże się w szczególności z ocena danych z zakresu medycyny, przy czym wydaje się, że chodzi nie tyle o percepcję empirycznych danych, ile o ich ewaluację w szerszym kontekście wymaganym przez pojęcie dobra dziecka.

Interesujące $\mathrm{w}$ debacie jest odnoszenie się do wolności religijnej. Wśród przeciwników dopuszczalności obrzezania pojawiały się głosy o nierelewantności tego prawa. Również wśród zwolenników jego dopuszczalności argumentowano, że ze względu na różne motywy rodziców, nie tylko religijne, kwestia dopuszczalności obrzezania wiąże się jedynie z prawem rodziców do wychowania dziecka. Pomimo zasadniczego znaczenia tego prawa, nie można wykluczyć zastosowania prawa do wolności religijnej. O ile „konstytucyjna ochrona decyzji o obrzezaniu [...] nie może zostać oderwana od prawa rodziców zgodnie z art. 6 ust. 2 UZ”, to „dla rodziców każde wykonywanie ich odpowiedzialności rodzicielskiej [...], w ramach którego włączają dziecko w praktykę religijna [...], jest zarazem realizacją ich własnej religii. W tym aspekcie pokrywaja się zakresy ochrony art. 6 ust. 2 zd. 1 i art. 4 ust. 1-2 UZ"112. Uważa się, że ewentualna ingerencja w religijnie motywowane wyobrażenia dobra dziecka wymagałaby dodatkowego usprawiedliwienia ${ }^{113}$, a pozycja prawna rodzica podejmującego decyzję o religijnym obrzezaniu ulega wzmocnieniu wobec państwa $^{114}$. Takie stanowisko wydaje się przekonujące. Trudno bowiem uznać, by ewentualny zakaz obrzezania, obejmujący istotna, wielowiekowa praktykę religijną żydów czy muzułmanów, w ogóle nie angażował zakresu treściowego prawa do wolności religijnej.

W wypowiedziach dyskutantów można niekiedy spotkać sformułowania świadczące o braku wrażliwości wobec fenomenu religii ${ }^{115}$. Podczas debaty parlamentarnej nad nowelizacja kodeksu cywilnego jeden z parlamentarzystów stwierdził: „[...] w naszym społeczeństwie nie ma już konsensusu w zakresie wolności religijnej [...]. Wielu ludzi w Niemczech ma stosunek obojętny wobec religii, część odrzuca religię, a niektórzy mają do niej wręcz wrogie nastawienie" 116 . Oczywiście czyjś stosunek do religii nie stanowi per se problemu prawnego ani teoretycznoprawnego. Nie można nadto utożsamiać nastawienia do religii ze stosunkiem do wolności religijnej. Niemniej zasadne wydaje się pytanie, czy utrata społecznej świadomości wartości i specyfiki pewnych dóbr chronionych konstytucyjnie może prowadzić do erozji ich ochrony praw-

\footnotetext{
112 M. Germann, op. cit., s. 417.

113 Ibidem, s. 418.

114 Por. Ch. Walter, op. cit., s. 1.

115 Por. uwagi H. Putzke i R. Merkel w: After Cologne: male Circumcision and the Law,

116 S. Thomae (FDP), w: Deutscher Bundestag, Protokół z 213 posiedzenia, s. 26073.
} op. cit., s. 445 . 
nej. Czy skoro dla istotnej części społeczeństwa religia nie tylko przestaje być, w sposób zreflektowany i aktywny, indywidualnie realizowanym dobrem, a nawet zanika przekonanie, że jest ona uniwersalnym i obiektywnym dobrem, nie dochodzi wówczas do utraty społecznego poczucia zasadności angażowania się państwa w ochronę tego dobra?

W debacie zastanawia również brak szerszej wrażliwości kulturowo-historycznej dyskutantów uznających obrzezanie za sprzeczne z prawami człowieka. Nie jest to rytuał, którego nowość stanowiłaby wyzwanie dla ustawodawcy państw demokratycznych. Zwyczaj ten od wieków praktykowany jest w judaizmie i islamie. Wydawałoby się, że europejska świadomość kulturowa, również w wymiarze prawnym, powinna być oswojona z faktem praktykowania tych religii. Można wprawdzie argumentować, że taka wrażliwość nie ma znaczenia dla argumentacji prawniczej, co więcej, że rolą porządku prawnego jest kwestionowanie tradycji kolidujących z jego aksjologia. Z punktu widzenia teoretycznoprawnego istotna wydaje sie jednak inna kwestia. Debata o obrzezaniu jest symptomatyczna dla zjawiska dynamicznej interpretacji regulacji prawnych chroniących prawa człowieka. Jak zauważono, „trudno sobie wyobrazić, by historyczny prawodawca konstytucyjny z 1949 r. akceptował, że sformułowane przez niego prawa podstawowe będą kiedyś użyte przeciwko żydowskiemu obrzędowi" ${ }^{117}$. Istotny jest przy tym fakt, że nieprzewidywalny przez prawodawcę „rozwój państwa i społeczeństwa” 118 nie polega w tym przypadku na pojawieniu się nowego zjawiska, ale na innej niż przyjmowana przez historycznego prawodawcę konstytucyjnego ocenie tego samego zjawiska. Wyjaśnieniem powyższego fenomenu ma być to, że „prawa podstawowe rozwijają się według właściwej im zasady indywidualizmu”, oraz „emancypacyjna tendencja, według której następuje rozwój praw człowieka i praw podstawowych"119. Obok pytań o kryteria ustalania i legitymację do orzekania o tym, czy i w jakim zakresie nastapił „rozwój” praw człowieka polegający na zmianie ich znaczenia, na przykładzie debaty o obrzezaniu można postawić pytanie o potencjalną ambiwalentność tego rozwoju. Hipotetycznie zakładając, że obecnie obrzęd ten należy uznać za niedopuszczalny w świetle postanowień konstytucji (niezależnie od stanowiska „historycznego prawodawcy konstytucyjnego"), sytuacja ta nie może być oceniona jako rozwój prawnej ochrony, biorac pod uwagę przysługujace rodzicom - wyznawcom judaizmu prawo do wychowania dziecka w związku z wolnością uzewnętrzniania wyznania przez uprawianie kultu, praktykowanie i czynności rytualne.

dr Pawet Eqcki

SWPS Uniwersytet Humanistyczny

Wydziat Zamiejscowy w Poznaniu

placki@swps.edu.pl

117 J. Isensee, op. cit., s. 323.

118 Ibidem, s. 324.

119 Ibidem. 


\section{CULTURAL CONDITIONS OF THE UNDERSTANDING HUMAN RIGHTS. THE GERMAN LAW STUDIES AND THE LEGALISATION OF DISPUTABLE RELIGIOUS PRACTICES}

\section{Summary}

There has been an intensive debate within the German law studies on the legal permissibility of circumcision of male children. The dispute that has now been going for several years seems to be focused on the question whether in the event of circumcision the child's interest is at risk, which would then constitute the grounds for the State's interference with the right of parents to direct the upbringing of their children.

The discussion on the legal permissibility of circumcision seems to constitute an exemplification of more general problems with which a democratic state of law (Rechtsstaat) as well as the theoretical reflection on law are confronted. Such problems include the definition of the essence and the limits of the right of parents to direct the upbringing of children, as well as the right to freedom of faith, a potential conflict of constitutional rights and freedoms, a dynamic interpretation of human rights related to the changing sensitivity with respect to protected goods, or finally the justification of the application of universal rules of law in the context of increasing cultural and axiological pluralism of modern societies. The following considerations present an overview of the development of the legal status of circumcision in Germany, as well as the main arguments raised in the German debate on the legal permissibility of circumcision. 